\title{
THE EFFECT OF TEACHER COMPETENCY ON PERFORMANCE APPRAISAL
}

\author{
Url Jurnal: https://uia.e-journal.id/akademika/article/1148 \\ DOI : https://doi.org/10.34005/akademika.v10i01. 1148
}

Submitted: 2020-12-07

Hendri Eka Jaya Putra

Universitas Pelita Harapan

hendriekajp1@gmail.com
Reviewed: 2020-09-01

Warsim

Universitas Pelita Harapan

warsimemail@gmail.com
Published: 2021-05-30

Peter Titirloloby

Universitas Pelita Harapan

petertitirloloby@gmail.com

\begin{abstract}
This paper is a research to analyse teacher competence on teacher performance appraisal at Junior High School (SMP) Marsudirini Bogor. This study investigates whether professional competence, pedagogic, competence personality and competence social competence have an influence on performance appraisal. Performance appraisal is a process of systematic evaluation of employee performance by paying attention to standards and how to communicate that information to them. The four competencies are integrative in the performance of teachers. In the performance appraisal, the instrument and process model used by the institution for teacher performance appraisal must address those four teacher competencies. This tool is an important part of performance management because it helps employees improve their performance This research uses a quantitative approach. This research is a causality study that uses multiple regression analysis techniques to see direct the effect of several independent variables on the dependent variable. The data analysis employs regression analysis using Smartpls version 3.3.2 for windows (Chin, 2010). In this study to analyze The variables used a Likert scale with five levels of assessment, namely Strongly Agree (SS), Agree (S), Neutral (N), Disagree (TS) and Strongly Disagree (STS). The sampling technique was purposive sampling, namely by selecting 45 teachers who had taught at least 1 year and had experienced teacher performance appraisals. The scores given start from 5 for SS answers to 1 for STS answers. The result of this study indicates that the four teacher competencies have an influence on teachers' performance appraisal. The results of data analysis prove that pedagogic competence is more dominant in shaping teacher performance appraisals. In general, although there is a clear correlation, the presentation of the effect of each competency on performance appraisal is still below $50 \%$. Schools are advised to look for strategies to further advance these four competencies which in turn will improve teacher performance. Social competence has the smallest effect (15.7\%) on teacher performance appraisal. The result of this study indicates that the four teacher competencies have an influence on teachers' performance appraisal. The results of data analysis prove that pedagogic competence is more dominant in shaping teacher performance appraisal by $38.9 \%$.
\end{abstract}

Keywords: Performance, Management, Performance Appraisal, Teacher competence. 235 | Akademika | Vol 10 | No. 1 | 2021 


\section{INTRODUCTION}

Human resource management includes planning, organizing, directing and monitoring employee performance which is known as performance management. According to (Dessler, 2003) performance management is the process of combining objectives, assessment and performance development in one unit to ensure employee performance is in line with the strategic objectives of the organization. To measure employee performance, a performance appraisal is conducted.

SMP Marsudirini Bogor conducts teacher performance appraisal that measures various teacher competencies. This performance appraisal includes several basic competencies which according to the law a teacher must possess. These competencies consist of professional competence, pedagogical competence, personality competence and social competence.

However, these assessments which routinely take place every year are often a mere formality. Teachers no longer consider this as something important. This encourages researchers to see the effect of teacher competence on performance appraisals at Junior High School, Marsudirini Bogor.

Based on this background, we propose the following research questions: 1) Does the teacher's competence affect the performance appraisal of teachers at SMP Marsudirini Bogor?, 2) How big is the influence of teacher competence on the performance of teachers at SMP Marsudirini Bogor?

\section{Competence}

Mulyasa (2004) defines competence as knowledge, skills and abilities that are mastered by someone and has become a part of him, so that he can perform cognitive, affective and psychomotor behaviors as well as possible.

\section{Performance}

Performance is the work achieved by employees during a certain period by comparing standards and targets that have been mutually agreed upon (Maryoto \& Susilo, 2000). According (Mangkunegara, 2017) high performance characteristics of an employee can be seen from his/her attitude that is responsible, ready to bear the risk, having realistic goals, having a work plan and striving to make it happen, using feedback in carrying out his duties and to look for opportunities to realize what has been programmed. 
According to llyas (1999) performance is the demonstration of work of individuals or work groups both quantity and quality in an organization. The description of performance involves three important components, namely: (1) Objectives: The determination of the objectives of each organizational unit is a strategy used to improve work; (2) Measurement: It takes a measure of whether a personnel has achieved the expected, for that quantitative and qualitative performance standards for each personnel duties and positions play an important role; (3) Assessment: Regular performance appraisal that is linked to the process of achieving the performance goals of each personnel. The definition of performance with a description of objectives, operational measures, and regular assessments has an important role in maintaining and increasing the motivation of personnel.

\section{Performance Management}

Performance management is an effort to obtain higher quality results by providing the facilities for individuals to support their duties within a mutually agreed framework. This involves a shared understanding of something that must be achieved and how to achieve it (Armstrong \& Taylor, 2014). Performance management is the process of ensuring that a series of activities and results meet organizational goals effectively and efficiently.

\section{Performance Appraisal}

Performance appraisal is a process of systematic evaluation of employee performance by paying attention to standards and how to communicate that information to them. This tool is an important part of performance management because it helps employees improve their performance (Mathis \& Jackson, 2015). The elements assessed based on Peraturan Pemerintah Nomor 10 Tahun 1979 are: responsibility, cooperation, honesty, obedience, loyalty, work performance, initiative and leadership.

According to Handoko, (2014) there are two kinds of assessment methods, past-oriented assessment methods and future-oriented assessment methods. Some of the assessments that are included in these methods are: rating scales, checklists, critical incident methods, field review methods, tests and job performance observations and group evaluation methods. This assessment method according to Handoko, (2014) includes: self-assessment (self appraisal), psychological assessment (psychological appraisals), Management By Objectives (MBO) approach and assessment center.

Law No. 14 of 2005 concerning Teachers and Lecturers, and Regulation of the Minister of National Education of the Republic of Indonesia 
Number 16 of 2007 concerning Academic Qualification Standards and Teacher and Lecturer Competencies indicate four competencies that teachers and lecturers need to have. The four competencies are: 1) Pedagogic

Competence, namely competence that requires teachers to be able to master learning theory that is tailored to the character, nature and interests of students. 2) Social Competence, which means that teachers have the ability to build relationships with fellow humans. 3) Personality

competence means an educator needs to have a sense. of pride in the trust given to him to prepare quality future generations. 4) Professional

Competence is the ability that teachers must have in terms of planning and implementing the learning process.

The four competencies are integrative in the performance of teachers. In the performance appraisal, the instrument and process model used by the institution for teacher performance appraisal must address those four teacher competencies.

\section{Conceptual Framework}

Based on the background discussed above there are four independent variables and one dependent variable in this research. The four independent variables are professional competence (X1), pedagogic competence (X2), personality competence (X3) and social competence (X4); whereas the dependent variable is performance appraisal $(Y)$.

Professional competence construct (X1), measured by 3 indicators, namely the ability to master material, structure, concepts, and scientific thought patterns that support the subjects being taught; ability to master competency standards and basic competencies in the subject / development area being handled); and the ability to develop creative learning materials.

Pedagogic competency construct (X2) includes the ability to master learning theory and teaching learning principles; ability to organize educational development activities; the ability to utilize information and communication technology for the benefit of implementing educational development activities; ability to uphold the code of ethics of the teaching profession; the ability to communicate effectively, empathically, and politely with students); and the ability to conduct assessment and evaluation of learning processes and outcomes.

Personality competency construct (X3) measured by 4 indicators, namely the ability to act in accordance with religious, legal, social, and national cultural norms of Indonesia; the ability to present oneself as an honest, noble character and role model for students and the Indonesian people; the ability to present oneself as a stable person; and the ability to be stable, mature, wise, and authoritative. 
Social competence construct (X4) measured by 6 indicators, namely the ability to communicate with students and parents of students); adaptability at work in all areas of the Republic of Indonesia which have socio-cultural diversity; ability to get along with colleagues and education partners; oral, written, and / or sign communication skills; the ability to use communication and information technology functionally; and the ability to get along effectively with students, fellow educators, educational staff, leaders of educational units, parents / guardians of students.

Performance appraisal construct $(\mathrm{Y})$ measured by 4 indicators, namely information related to performance appraisal), indicators in performance appraisal, performance appraisal results, and feedback from performance appraiser.

The application used to process data is the SmartPLS Version 3 (Wong, 2018). The output of the PLS Algorithm and BOOTSTRAP calculations is as follows.

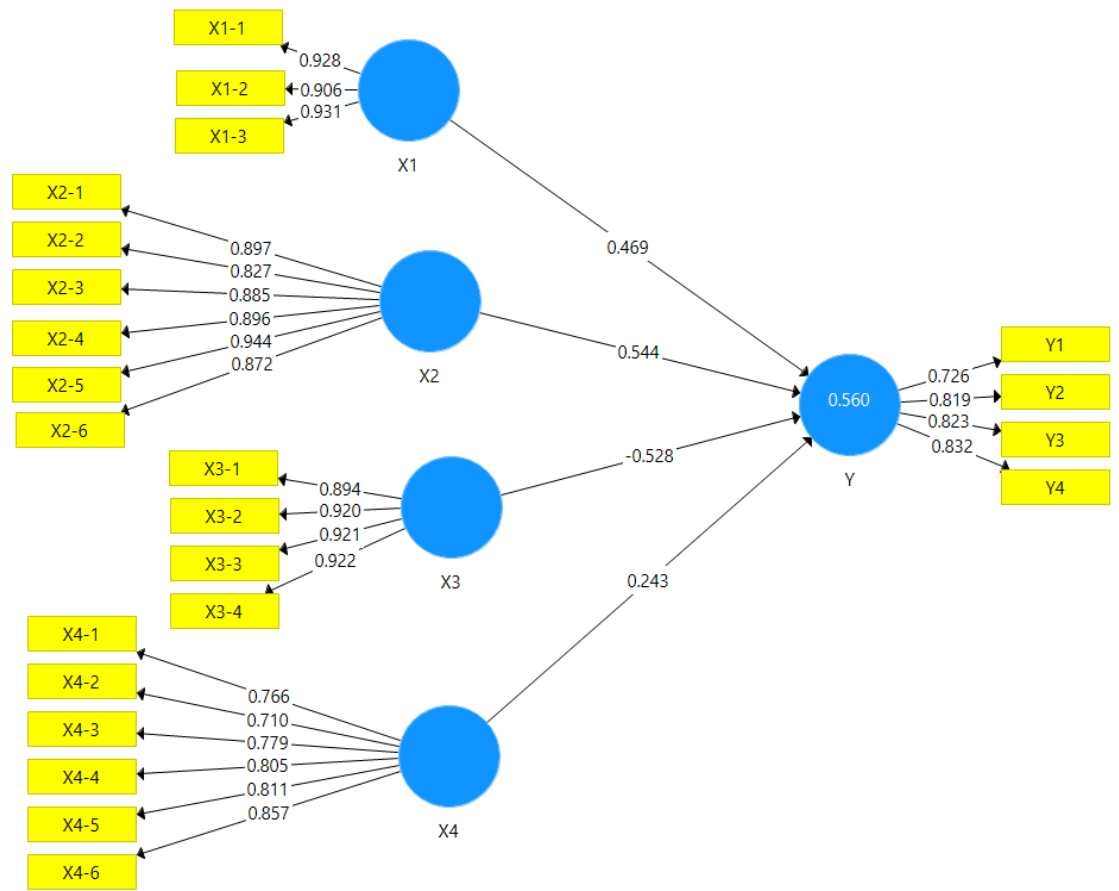

Figure 1. The results of the PLS Algorithm Calculation

\section{Hypothesis}


Based on the description above, the researchers set the research hypothesis as follows:

Professional, pedagogic, personality and social competence have an influence on teacher performance appraisal at SMP Marsudirini Bogor.

\section{METHOD}

This research is a causality study that uses multiple regression analysis techniques to see direct the effect of several independent variables on the dependent variable.

\section{Operational Definition of Variables}

Professional competence component (X1) is measured by 3 indicators, namely:

X1.1 Ability to master material, structure, concepts, and scientific mindsets that support subject matter.

X1.2 Ability to master competency standards and basic competencies of subjects / fields Development that is guided).

X1.3 Ability to develop learning materials that are taught creatively. namely:

Pedagogic competence component (X2) is measured by 6 indicators,

X2.1 Ability to master learning theory and teaching learning principles.

X2.2 Ability to carry out development activities educate.

X2.3 Ability to utilize information and communication technology for the benefit of implementing educational development activities.

X2.4 Ability to uphold the professional code of ethics of teachers.

X2.5 Ability to communicate effectively, empathically, and politely with students.

X2.6 Ability to conduct assessments and evaluations Process and learning. namely:

Personality competence component $(\mathrm{X} 3)$ is measured by 4 indicators,

X3.1 Ability to act in accordance with Indonesian religious, legal, social and cultural. 
norms X3.2 Ability to present oneself as an honest, noble character, and role model for students and Indonesian society.

X3.3 Ability to present oneself as a solid person.

X3.4 Ability to be stable, mature, wise, and authoritative.

Social competence component (X4) is measured by 6 indicators, namely:

X4.1 Ability to communicate with students and parents students.

X4.2 Ability to adapt at work in all regions of the Republic of Indonesia which has socio-cultural diversity.

X4.3 Ability to get along with colleagues and partners Education.

X4.4 Ability to communicate in oral, written, and / or gestures.

X4.5 Ability to use technology communication and information functionally.

X4.6 Ability to get along effectively with students, fellow educators, education staff, unit leaders education, parents / guardians of students.

Performance appraisal component $(\mathrm{Y})$ is measured by 4 indicators, namely:

Y1 Information related to performance appraisal.

Y2 Indicators in performance appraisal.

Y3 Results of performance appraisal.

Y4 Feedback from assessors.

\section{Measurement of Variables}

In this study to analyze The variables used a Likert scale with five levels of assessment, namely Strongly Agree (SS), Agree (S), Neutral (N), Disagree (TS) and Strongly Disagree (STS). The scores given start from 5 for SS answers to 1 for STS answers.

\section{Population and Research Sample}

The population consisted of all SMP Marsudirini Bogor teachers. The sampling technique was purposive sampling, namely by selecting teachers who had taught at least 1 year and had experienced teacher performance appraisals.

Time and Location of Research

Research was carried out through online questionnaires using google form on September 20-27 2020. 


\section{Data Collection}

(i) Primary data is obtained through field research by distributing questionnaires to respondents to be filled in and returned to researchers according to time. set. (ii) The secondary data required is in the form of supporting data such as the teacher's educational background, age and years of service.

Data collection was carried out using a questionnaire. Researchers make questionnaires in accordance with the objectives of research related to teacher performance appraisal. The researcher then formulated 34 questions. These questions consist of questions related to teacher performance appraisal, pedagogical competence, personality competence, social competence and professional competence.

\section{Data Analysis Technique}

Applications used to process data are using the SmartPLS Version 3 application (Wong, 2018). Data analysis technique uses multiple regression analysis as follows:

$\mathrm{Y}=\mathrm{X} 1+\mathrm{X} 2+\mathrm{X} 3+\mathrm{X} 4$

Where:

$Y=$ performance appraisal (dependent variable)

$\mathrm{X} 1=$ professional competence (independent variable)

$\mathrm{X} 2$ = pedagogic competence (independent variable)

$\mathrm{X} 3=$ personality competence (independent variable)

$\mathrm{X} 4$ = social competence (independent variable)

\section{RESULTS}

\section{Validity Test}

To see the validity of the AVE (average variance extracted) test was conducted. The indicator is said to be valid if AVE >0.5.

Table 1. AVE (Average Variance Extracted)

\begin{tabular}{cc}
\hline Construct & AVE \\
\hline X1 & 0.849 \\
X2 & 0.788 \\
& \\
X3 & 0.836 \\
X4 & 0.623 \\
Y & 0.642 \\
\hline
\end{tabular}


It is clear from Table 1 above that all variable values are greater than 0.5 . Then this data can be declared valid.

Furthermore, after testing AVE, it is necessary to test discriminant validity, which is to test the value of the variable of each indicator against its construct. This test is declared valid if the value of each variable is greater in the construct than the other variables.

Table 2. Discriminant Validity

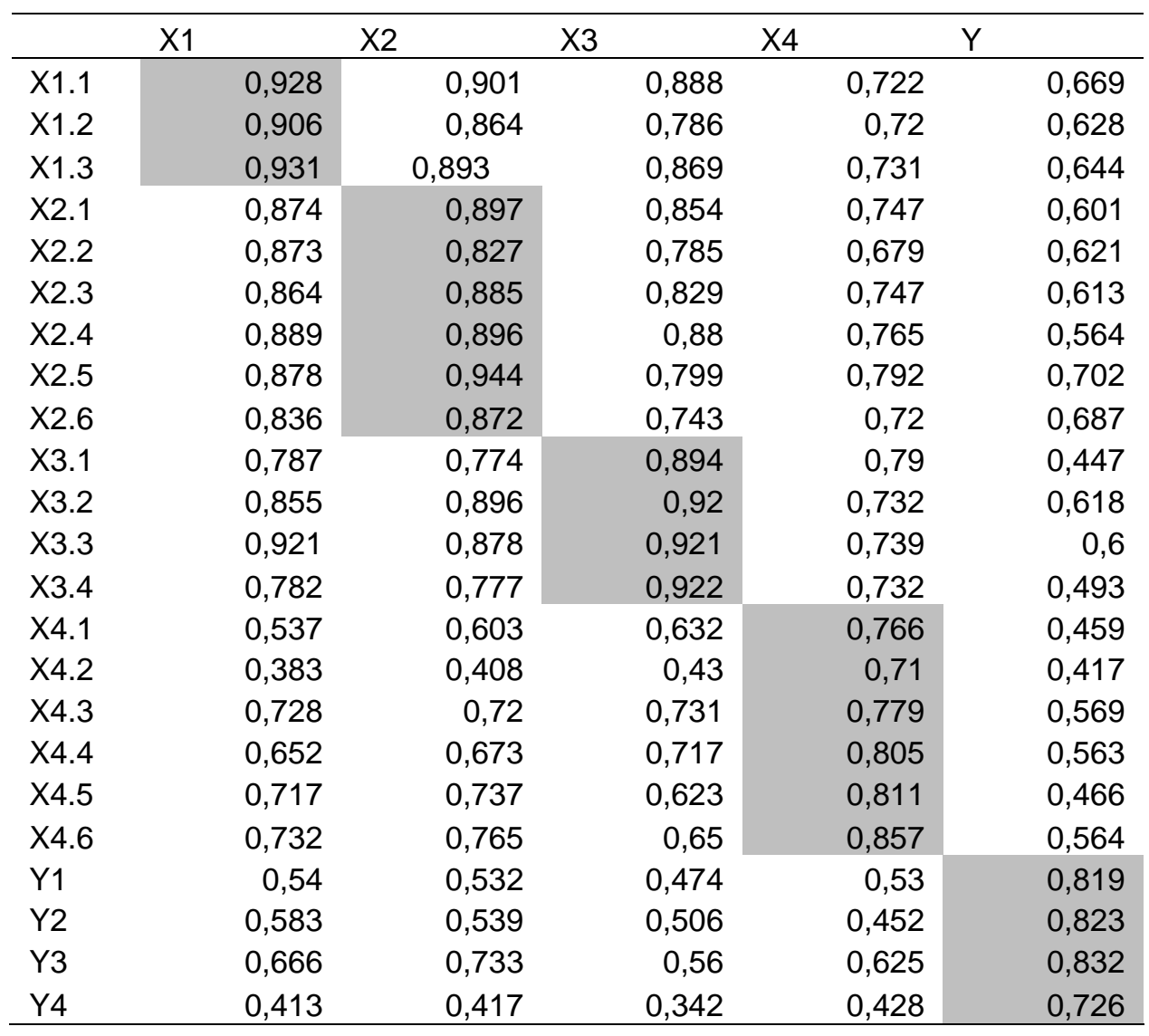

Testing the value of each variable against the construct as shown in Table 2 above, is said to be valid if the value is above 0.7 . From the results of the external loading test, it can be declared valid because all values are greater than 0.7 . 


\section{Correlation Analysis}

To determine the relationship of the independent variables (professional, pedagogic, personality and social competence) to the dependent variable (performance appraisal), a linear regression analysis was used.

The effect of each independent variable $(X 1, X 2, X 3$ and $X 4)$ on the dependent variable $(\mathrm{Y})$ is illustrated in table 3 below.

Table 3. Path Coefficients

\begin{tabular}{lll}
\hline Path & Value & Effect \\
\hline$X 1->Y$ & 0.469 & Direct \\
$X 2->Y$ & 0.544 & Direct \\
$X 3->Y$ & -0.528 & Direct \\
$X 4->Y$ & 0.243 & Direct \\
\hline
\end{tabular}

From the table above, it can be explained as follows:

- Professional competence has an influence on performance appraisal of 0.469

- Pedagogical competence has influence on the performance assessment of 0,544

- Competence personality has an influence on the performance ratings of 0.528

- social competence has an influence on the performance ratings of 0,243

Furthermore, to calculate the percentage effect of each variable on performance appraisal, it is calculated from the path Latent variable Correlation coefficient $\mathrm{x}$ ) $\times 100 \%$, as follows:

Table 4. Effect of Variables

\begin{tabular}{ll}
\hline Variable & Effect $\%$ \\
\hline X1 & $0,702 \times 0,469=32,9 \%$ \\
X2 & $0,715 \times 0,544=38,90 \%$ \\
X3 & $0,6 \times-0,528=31,68 \%$ \\
X4 & $0,649 \times 0,243=15,77 \%$ \\
\hline
\end{tabular}

Thus we obtain an equation as follows:

$$
Y=0.469 X 1+0.544 X 2-0.528 X 3+0.243 X 4
$$




\section{DISCUSSION}

Pedagogic competence has an influence on performance appraisal by $38.9 \%$. Pedagogic competence is influenced by the ability to carry out educational development activities, the ability to carry out assessment and evaluation of learning processes and outcomes, the ability to utilize information and communication technology for the benefit of organizing educational development activities, the ability to uphold the professional code of ethics of the teacher, the ability to master learning theory and principles educational learning principles, as well as the ability to communicate effectively, empathically, and politely with students.

Personality competence has an influence on performance appraisal of $31.68 \%$, Personality competence is influenced by the ability to act in accordance with the norms of religion, law, social and national culture of Indonesia, the ability to present oneself as an honest, noble character, and role model for students and Indonesian society, the ability to present oneself as a stable person, and the ability to be stable, mature, wise, and authoritative.

Social competence has an influence on performance appraisal by $15.7 \%$. Social competence is influenced by the ability to adapt at work in all regions of the Republic of Indonesia which has socio-cultural diversity, the ability to communicate with students and parents of students, the ability to get along with colleagues and education partners, oral, written communication skills, and / or cues, the ability to use communication and information technology functionally, as well as the ability to get along effectively with students, fellow educators, educational staff, heads of educational units, parents / guardians of students.

Teacher performance appraisal triggers an increase in teacher competence from time to time. The results of research on teacher professional competence provide encouragement to teachers to continue improving their abilities in various ways, especially in terms of competence. (Kagema \& Irungu, 2018) in their study in Kenya concluded that teacher performance appraisal affects teacher performance. They see teacher assessment as an important vehicle for improving the quality of education. Teacher assessments are believed to have the potential to facilitate teacher professional development and to stimulate learning improvement.

We found that teacher competence is broken down into several types of competencies. We map each competency to see accurately the contribution of these competencies to performance appraisal. This is in line with what (Jonsson, 2008) argues. He found in his research that assessment 245 | Akademika | Vol 10 | No. 1 | 2021 
of competencies is a complex undertaking, and as has been noted, each particular mode of assessment has a number of sources of error and a set of restrictions. This means that any single assessment method is not sufficient to "capture" the full spectrum of skills in the target domain in a credible way.

(Elliott, 2015), in his research Teacher Performance Appraisal: More about Performance or Development?, argued that the key to effective appraisal is getting the balance right between assessing performance and assisting personal development. In line with what Elliot said, the data presented above shows the importance of professional development for teachers to support their performance appraisal. The better the competence of the teacher, the better the results of their assessment. Thus the school does not only assess but should encourage and facilitate the selfdevelopment of teachers.

\section{CONCLUSION}

Based on several interpretations that have been described above and also based on the results of these equations, it can be concluded that pedagogic competence is more dominant in shaping teacher performance results.

In general, although there is a clear correlation, the presentation of the effect of each competency on performance appraisal is still below $50 \%$. Schools are advised to look for strategies to further advance these four competencies which in turn will improve teacher performance.

Social competence has the smallest effect (15.7\%) on teacher performance appraisal. For this reason, the school needs to pay attention to the elements that support this competency so that it can increase in the future.

Further research is needed to determine the performance appraisal model which emphasizes the quality more than the large number of items of the assessment instrument used. 


\section{REFERENCES}

Armstrong, M., \& Taylor, S. (2014). Handbook of Human Resource Management Practice (13th ed.). Kogan Page Limited.

Chin, W. W. (2010). Handbook of Partial Least Squares. In Handbook of Partial Least Squares (Issue January 2010). https://doi.org/10.1007/9783-540-32827-8

Dessler, G. (2003). Manajemen Sumber Daya Manusia. PT Indeks.

Elliott, K. (2015). Teacher performance appraisal: More about performance or development? Australian Journal of Teacher Education, 40(9), 102-116. https://doi.org/10.14221/ajte.2015v40n9.6

Handoko. (2014). Manajemen Personalia dan Sumber Daya Manusia. BPFE UGM.

llyas, Y. (1999). Kinerja. Badan Penerbit FKM UI.

Jonsson, A. (2008). Educative assessment for/of teacher competency. In Assessment in Education (Vol. 17, Issue 1).

http://proquest.umi.com/pqdweb?did=1979837691\&Fmt=7\&clientld $=1126$ $3 \& R Q T=309 \& V$ Name $=P Q D$

Kagema, J., \& Irungu, C. (2018). an Analysis of Teacher Performance Appraisals and Their Influence on Teacher Performance in Secondary Schools in Kenya. International Journal of Education, 11(1), 93. https://doi.org/10.17509/ije.v11i1.11148

Mangkunegara, A. P. (2017). Manajemen Sumber Daya Manusia Perusahaan. Remaja Rosdakarya.

Maryoto, \& Susilo. (2000). Manajemen Sumber Daya Manusia. BPFE UGM. Mathis, R. L., \& Jackson. (2015). Factors Affecting Individual Performance. Mulyasa. (2004). Kurikulum Berbasis Kompetensi Konsep, Karakteristik, dan Implementasi (6th ed.). Remaja Rosdakarya.

Wong, K. K.-K. (2018). Praise for Mastering Partial Least Squares Structural Equation Modeling (PLS SEM) with SmartPLS in 38 Hours "PLS-SEM. October, 12(9), 596-598. http://www.ncbi.nlm.nih.gov/pubmed/21226399

Pemerintah Indonesia. (2005). Undang-Undang Nomor 14 Tahun 2005 tentang Guru dan Dosen. In Sekretariat Negara. Cintra Umbara. 